Vol. 3, No. 1, pp. 45-52, 2022

\section{Illegal Levies as a Negative Element Contributing to The Decrease of The Tourism Potential on Madura}

\author{
Tolib Effendi $^{1 *}$, Rusmilawati Windari ${ }^{2}$ \\ ${ }^{1,2}$ Faculty of Law, University of Trunojoyo Madura, Bangkalan, Indonesia \\ *Corresponding author mail: te.effendi@gmail.com
}

\begin{abstract}
As revealed by the World Economic Forum, there is a correlation between corruption and tourism: the higher the level of corruption of a state, as reflected in the Corruption Perceptions Index of Transparency International, the lower the number of foreign tourists visiting the state. As such, a very strong correlation exists between the community development index, tourism, and the community's legal awareness on the journey to the eradication of illegal fees. Illegal fees have to date been regarded as something normal in society. Illegal fees have become a regular in every sector, which must be ceased, and this holds true to the tourism sector as well. It is thus become essential to study the correlation between illegal fees in the tourism sector and the undermined tourism potential on Madura. Illegal fees have become part of the systems applied in Indonesia, including in the tourism sector. One of the reasons behind visitors' disinterest in visiting a tourist attraction is the illegal fees someone imposes there, whether they be in the form of entrance fees or in the form of parking fees. The absence of a price standard allows some irresponsible persons to collect such fees as entrance and parking fees at tourist attractions variably according to the situation that arises in a given time. This paper uses a socio-legal research method to investigate directly into the relationship between illegal fees in the tourism sector and the undermined tourism potential on Madura. Primary data, collected through interviews, survey, and observation, were analyzed descriptively. The main finding is low correlation between illegal fees and the undermined tourism potential on Madura and there are some indications that illegal fees are charged to tourist locations that have small popularity in each regency or that, conversely, these illegal fees cause these tourist loctions to lose their visitors.
\end{abstract}

Keywords: Tourism, Corruption, Illegal Fees

\section{Introduction}

Prior to 1970, development was viewed as none other than just an economic phenomenon. However, as time passes by, it may come to one's mind as realization that a high degree of economic development does not necessarily guarantee an improvement to the standard of living of the greater part of a population. Empirical data suggest that some states that have arrived at an elevated point in economic development still face unemployment, poverty, and other social issues pertaining to human beings. In 1990, the United Nations Development Programme (UNDP) elaborated that human are the real assets of a nation. Human development places humans as the ultimate goal of development as opposed to just an input of development (Hamzah et al., 2012; Kusharjanto and Kim, 2011). Therefore, the primary aim of development is to create an environment that allows the society to enjoy longevity, health, and productive life. In the same year, the UNDP established three dimensions that make up the human development index in describing human life quality, namely 1) a long and healthy life, 2) knowledge, and 3) decent standard of living (Sofilda et al., 2015; Fattah and Muji, 2012).

The human development index is a critical indicator in the measurement of success to build human life quality (society/population). This index is capable of determining the level of development of a region/state. For Indonesia, this index represents strategic data as in addition to being a measure of government performance it is also used as an allocator in the determination of the General Allocation Fund (DAU) of a region/locality (Niswaty et al., 2015; Rahmat et al., 2021; Amaluddin et al., 2018).

As revealed by UNDP data, in 2019 Indonesia belonged to the High Human Development group at the 107th spot, higher than the Philippines and Vietnam but well behind Malaysia, Brunei, and especially Singapore, all of which were in the Very High Human Development group. Indonesia's human development index trend in 1990, 2000, 2010, 
and 2019 shows that in approximately three last decades the state has been undergoing a stable increase. This trend of human development index of the state can be seen in more detail in the Figure 1.

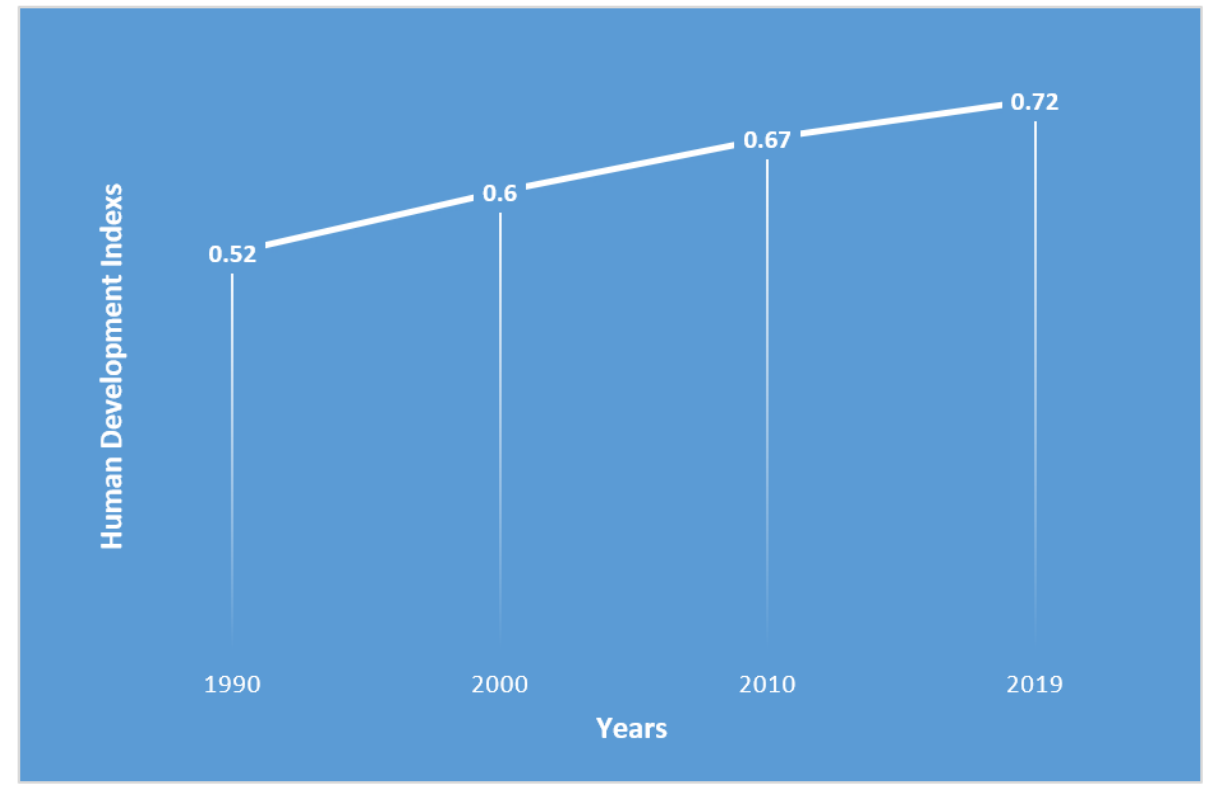

Figure 1. Indonesian Human Development Index 1990 - 2019

On a narrower scale, that is province- and regency-wise, East Java ranks 15th in Indonesia's human development index. Within the last ten years, Surabaya City tops the index in the scope of East Java, while, in the same time frame, Sampang Regency rests at the bottom. As broken down by the UNDP, the indicators of the measurement of the human development index seen from the three dimensions - a long and healthy life, knowledge, and decent standard of living - include the number of people in poverty, the number of working people, open unemployment rate, and per capita income, to name just a few. Other than Sampang Regency, three other regencies on Madura are also among the lowest 10 on the human development index in East Java (Susilowati et al., 2019; Idialis, 2020).

Madura Island is one of the major islands off Java Island which is still part of East Java Province. There are also 126 other small islands scattered around Sumenep Regency. The fact that all the regencies on Madura are directly bordered by the sea gives those regencies an undeniable coastal tourism potential (Sudarmo, 2020). Every regency on Madura has a natural tourism potential that needs to be optimized. However, the tourism riches on Madura are not only limited to the nature; they also extend to historical, cultural, and religious tourism categories. These riches may constitute only a minor part of the immense tourism potentials remaining to be massively explored. Constructive measures are required to manage and develop some of those potentials to meet the central government's goal to strengthen local wisdom and cultures as Indonesia's local wealth that must be conserved (Farida et al., 2019; Windari and Effendi, 2021; Nugraha, 2020).

Sampang Regency, a region with the lowest community development index score in East Java, in fact has a fair tourism potential. The Culture, Tourism, Youth, and Sports Service of Sampang Regency divided tourism into three major categories, namely natural, cultural, and archeological tourism, each with a sizeable potential. Nonetheless, the tourism sector in Sampang Regency is insignificant in its contribution to Sampang Regency's Locally Generated Income. The main reason is that tourism is not a strategic issue in the eye of the committed stakeholders of Sampang Regency, who see many other programs and sectors as possible development options and priorities. Moreover, the response and awareness of society as well as investors in the tourism sector regarding tourism are low. Attracting investors from beyond Madura or even from another country may serve as a way to increase the regional income of Sampang Regency as well as other regencies on Madura for the purpose of improved community development index positioning of the Madura area (Rahayuningish, 2021; Ekawati et al., 2021).

When it comes down to investment in the tourism sector, there is another matter in need of a closer look: corruption potential in the tourism sector (Pusra et al., 2021). In 2019, the Corruption Eradication Commission (KPK) was focused on disseminating a guide to prevent corruption in the business world to improve corruption prevention awareness, abilities, and skills in Indonesia. The collaboration with the business realm can strengthen and improve the anti-corruption network in taking collective actions and making contributions to the attainment of the targets of corruption prevention strategies in the private sector. There are eight priority sectors aimed by the Corruption Eradication Commission: 1) forestry; 2) financial services; 3) oil and gas; 4) telecommunications; 5) health; 6) food; 7) infrastructure; and 8) air transportation \& logistics. Although there is no specific mention of the tourism sector among the Corruption-Eradication-Commission-targeted priority sectors, investments made in relation to tourism development always involve financial services and infrastructure. One of the instances of corruption in the tourism 
sector is the extortion involved in the proposal of a tourist area development permit for a golf course in Lombok, West Nusa Tenggara, in which the then incumbent Regent of Lombok Barat was implicated (Fallon, 2001).

Related to the recovery of the tourism sector that has been hit by the COVID-19 pandemic, not only investments are increased, but corruption potential too is elevated, given that the government has allocated a tourism grant fund. On Bali, the tourism grant fund disbursed to business players and local governments is also subject to corruption. Other than the big-scale corruption that has the shape of extortion involved in investment permits as well as the tourism grant fund corruption, there also takes place corruption on the small scale that involves the bottommost structure in society, namely village governments. This smaller-scale corruption takes the form of illegal fees. These illegal fees have to date been regarded as something normal in society. Illegal fees have become a regular in every sector, which must be ceased (Wantara and Irmawati, 2021).

Indications of illegal fees practice are also present in some tourist attractions on Madura. Preliminary information indicates that illegal fees are charged at tourism attractions in Lombang Beach in Sumenep, Jaddih Limestone Hill in Bangkalan, and Arosbaya Cave in Bangkalan. It shows that the tourism sector has also been exposed to illegal fees. However, according to the Police or the Illegal Fees Eradication Task Force in each region, including Bangkalan, Sampang, Pamekasan, and Sumenep Regencies, there have been no reports on illegal fees at tourist attractions filed. The illegal fees imposition cases the local Police or the Illegal Fees Eradication Task Force has handled are those that took place on marketplaces or other services (Funna, 2020).

As revealed by the World Economic Forum, there is a correlation between corruption and tourism: the higher the level of corruption of a state, as reflected in the Corruption Perceptions Index of Transparency International, the lower the number of foreign tourists visiting the state. Article 4 of Law No. 10 of 2009 on Tourism explains the goals of tourism to be a) to boost the economic growth, b) to improve the people's prosperity, c) to eradicate poverty, d) to tackle unemployment, e) to conserve the nature, environment, and resources, f) to nurture culture, g) to lift the image of the nation, h) to foster the love of the motherland, i) to reinforce the identity and integrity of the nation, and j) to strengthen the relationship between nations. Based on that provision, a strong correlation exists between the community development index, tourism, and the community's legal awareness in the effort to eliminate corruption and illegal fees.

To lift Madura's position on the community development index, one can provide sound education, including education on anti-corruption, and enable a decent standard of living through the increase in the community's income, which can be realized in a variety of avenues, including tourism. Both may happen if the community shares the awareness to develop tourism as one of the focuses of community development as well as legal awareness to get rid of corruption and illegal fees. According to the background description above, the focus of this research is studied of the correlation between illegal fees at top tourist locations and the causes of undermined tourism potential on Madura.

\section{Research Methods}

This research is a socio-legal study with an alternative approach to examining a doctrinal study into the law. In this research the correlation between illegal fees at top tourist locations and the causes of undermined tourism potential on Madura is to be examined. Serving as research locations here are the four regencies on Madura. Madura is chosen as a model in this research especially because it has a marine tourism potential that tends to be comparable to areas that have gained popularity earlier such as Bali and Lombok. The data collected are primary data. These data were collected using the data collection methods of interview, questionnaire survey, and observation. The data collected are analyzed evaluatitatively, and the results are justified by the researchers. In this research, the data collected are to give justification to whether there is an effect of corruption and illegal fees on the development of the tourism potential on Madura.

\section{Results and Discussion}

Madura, a major island in East Java whose long coastline runs not only west to east but also south to north, is outlined with beaches with varying characteristics. Given such a geographical condition, the island is akin geographically to Bali and Lombok, which render their beaches top tourist destinations. Aside from its beaches, religious tourism is a tourism potential attractive to tourists visiting the island, especially to those who adhere to Islam.

Based on the Table 1, there are a total of 77 tourist destinations officially licensed by the Culture and Tourism Services on Madura, including 16 marine tourist attractions and 18 religious ones, which make up $44 \%$ of the total tourism potentials on the island. Based on the data aforementioned, nearly half of the tourist destinations on Madura are in the marine and religious tourism categories. The concepts underlying these two types of tourism are poles apart, thereby requiring tourism potential development concepts that are distinguishable from one another. 
Table 1. Recapitulation of the Tourist Destinations on Madura

\begin{tabular}{|c|c|c|}
\hline Regency & No & Tourist Destinations \\
\hline \multirow[t]{21}{*}{ Bangkalan } & 1 & Kokop Waterfall \\
\hline & 2 & Galis Waterfall \\
\hline & 3 & The Natural Flame of Konang \\
\hline & 4 & Jaddih Limestone Hill \\
\hline & 5 & Mount Geger \\
\hline & 6 & Sepulu Mangrove Forest \\
\hline & 7 & Kerapan Sapi Attraction \\
\hline & 8 & Kolla Langgundih \\
\hline & 9 & Aer Mata Ebu Cemetary \\
\hline & 10 & The Tomb of Sultan Abdul Kadirun \\
\hline & 11 & The Tomb of Sunan Cendana \\
\hline & 12 & The Tomb of Syeichona Cholil \\
\hline & 13 & Sembilangan Lighthouse \\
\hline & 14 & The Museum of Bangkalan \\
\hline & 15 & Pantai Biru \\
\hline & 16 & Bumi Anyar Beach \\
\hline & 17 & Maneron Beach \\
\hline & 18 & Rongkang Beach \\
\hline & 19 & Siring Kemuning Beach \\
\hline & 20 & Pelalangan \\
\hline & 21 & Bangkalan Urban Recreation Park \\
\hline \multirow[t]{13}{*}{ Sampang } & 1 & Toroan Waterfall \\
\hline & 2 & Lebar Cave \\
\hline & 3 & Nepa Forest \\
\hline & 4 & Mandangin Coral Reef \\
\hline & 5 & Aji Gunung Fishing Ponds \\
\hline & 6 & Sumber Oto' Swimming Pool \\
\hline & 7 & Tujuh Panji Laras Cemetary and Well \\
\hline & 8 & The Resting Place of Sayid Utsman \\
\hline & 9 & Camplong Beach \\
\hline & 10 & Lon Malang Beach \\
\hline & 11 & Rato Ebu Site \\
\hline & 12 & Trunojoyo Site \\
\hline & 13 & Klampis Dam \\
\hline \multirow[t]{14}{*}{ Pamekasan } & 1 & The Eternal Flame of Pamekasan \\
\hline & 2 & Brukoh Hill \\
\hline & 3 & Kehi Hill \\
\hline & 4 & Salt Edutourism \\
\hline & 5 & Mangrove Ecotourism \\
\hline & 6 & Toron Semalem Village \\
\hline & 7 & Durian Village \\
\hline & 8 & Mandhilaras Museum \\
\hline & 9 & Jumiang Beach \\
\hline & 10 & Talang Siring Beach \\
\hline & 11 & Batu Ampar Cemetary \\
\hline & 12 & Ratu Summit \\
\hline & 13 & Avalokitesvara Temple \\
\hline & 14 & Rice Field Tour \\
\hline \multirow[t]{6}{*}{ Sumenep } & 1 & Asta Gumuk \\
\hline & 2 & Asta Jokotole \\
\hline & 3 & Asta K. Faqih \\
\hline & 4 & Asta Katandur \\
\hline & 5 & Asta Panaongan \\
\hline & 6 & Asta Sayid Yusuf \\
\hline
\end{tabular}




\begin{tabular}{lll}
\hline & Gili Iyang \\
8 & Gili Labak \\
9 & Goa Kuning \\
10 & Soekarno Cave \\
11 & Asta Tinggi \\
12 & Kedatim Mangrove Tourism \\
13 & Jami Mosque Sumenep \\
14 & The Museum of the Palace of Sumenep \\
15 & Mutiara Tirta \\
16 & Badur Beach \\
17 & E Kasoghi Beach \\
18 & Lombang Beach \\
19 & Sembilan Beach \\
20 & Slopeng Beach \\
21 & Kampung Kasur Pasir \\
22 & Batu Gong Site \\
23 & Kalimo’ok Fort \\
24 & Tektona Waterpark \\
25 & Tirta Sumekar Indah \\
26 & Sumekar Waterpark \\
27 & Limestone Tourism \\
28 & Kalompek Hill \\
29 & Bukit Tinggi \\
77 & \\
\hline
\end{tabular}

Data Source: Abstracted from the Culture and Tourism Services of the four regencies on Madura

From the 77 tourist attractions on Madura listed above, the top three destinations of each regency with the most numbers of visitors within the time period 2017-2019 (prior to the COVID-19 pandemic) based on the data from the Culture and Tourism Service of each regency can be seen in Table 2.

Table 2. Recapitulation of the Numbers of Visitors at the Tourist Destinations on Madura in the Period 2017-2019 (Top Three/Regency)

\begin{tabular}{lllll}
\hline Regency & No & Tourist Destinations & $\begin{array}{l}\text { Number } \\
\text { Visitors }\end{array}$ & of \\
\hline Bangkalan & 1 & $\begin{array}{l}\text { The Tomb of Syeichona Cholil } \\
\text { Aer Mata Ebu Cemetary }\end{array}$ & $3,279,307$ & $\mathbf{5 2 \%}$ \\
& 2 & $\begin{array}{l}\text { The Tomb of Sultan } \\
\text { Sampang Abdul }\end{array}$ & 147,5979 & $41 \%$ \\
& 1 & Kadirun & $2 \%$ \\
& 2 & Lon Malang Beach* & 672,566 & $\mathbf{5 2 \%}$ \\
Pamekasan & 3 & Noroan Waterfall & 219,416 & $17 \%$ \\
& 1 & Batu Ampar Cemetary & 145,839 & $11 \%$ \\
Sumenep & 2 & Jumiang Beach & 152,679 & $\mathbf{3 3 \%}$ \\
& 3 & Talang Siring Beach & 133,953 & $29 \%$ \\
& 1 & Asta Tinggi & 109,036 & $24 \%$ \\
& 2 & Asta Sayid Yusuf & 828,599 & $\mathbf{2 3 \%}$ \\
& 3 & Asta Panaongan & 616,433 & $17 \%$ \\
\hline
\end{tabular}

Data Source: Abstracted from the Culture and Tourism Services of the four regencies on Madura Note: *Lon Malang Beach was first opened in 2018

Based on the Table 2, the tourism in Bangkalan Regency is dominated by the religious tourism sector with the Tomb of Syeochona Cholil, Aer Mata Ebu Cemetary, and the Tomb of Sultan Abdul Kadirun making up the 95\% share of the total visits. In Sumenep Regency, visits to Asta Tinggi, Asta Sayid Yusuf, and Asta Panaongan account for $48 \%$ of the total visits to the regency, whereas 33\% visitors to Pamekasan Regency are singly headed to Batu Ampar Cemetary. Only Sampang Regency is not under the domination of religious tourism; $80 \%$ of the visits to the regency fall into the natural tourism category, and a meagre $4 \%$ does into the religious tourism category. 
After a questionnaire survey was conducted, a contrasting set of data was collected. This difference is caused by the presence of some specific predetermined variables:

a. Respondent Age and

b. Respondent Domicile.

In the variable Respondent Age, $75 \%$ of the respondents are in the age range 15-21 years, $23 \%$ are in the age range 22-27, and only $2 \%$ are beyond 28 years old. In the variable Respondent Domicile, $60 \%$ of the respondents are domiciled on Madura, and the rest live outside Madura. According to the data derived from 320 respondents through a questionnaire that uses open-ended and close-ended questions, the respondents' three most visited tourist attractions on Madura among those included on a provided list of tourist attractions are as follows: Jaddih Limestone Hill in Bangkalan (39.8\%); 2) Slopeng Beach in Sumenep (35.4\%), and 3) Camplong Beach in Sampang. The data are provided in Table 3.

Table 3. Recapitulation of the Tourist Destinations on Madura Based on the Questionnaire Survey

\begin{tabular}{clc}
\hline No & \multicolumn{1}{c}{ Tourist Destination } & Percentage* \\
\hline 1 & Jaddih Limestone Hill in Bangkalan & $39.8 \%$ \\
2 & Slopeng Beach in Sumenep & $35.4 \%$ \\
3 & Camplong Beach in Sampang & $35 \%$ \\
4 & The Eternal Flame of Pamekasan in Pamekasan & $33 \%$ \\
5 & Lon Malang Beach in Sampang & $29.6 \%$ \\
6 & Sembilan Beach in Sumenep & $28.9 \%$ \\
7 & Talang Siring Beach in Pamekasan & $25.2 \%$ \\
8 & Tlangoh Beach in Bangkalan & $21.1 \%$ \\
9 & E Kasoghi Beach in Sumenep & $17.4 \%$ \\
10 & Bangkalan Urban Recreation Park in Bangkalan & $17.3 \%$ \\
11 & Ratu Summit in Pamekasan & $14.3 \%$ \\
12 & Lebar Cave in Sampang & $9.2 \%$ \\
\hline
\end{tabular}

Data Source: Abstracted from the Questionnaire Survey

Based on the answers to the open-ended question, the three tourist attractions most frequently visited by the respondents are Lombang Beach in Sumenep (17\%), Jumiang Beach in Pamekasan (9\%), and Padelegan in Pamekasan (4\%). Seventy percent other respondents visited a variety of other destinations from Bangkalan to Sumenep. Other than measuring the popularity of the tourist destinations on Madura, the questionnaire that was distributed to the respondents also measures two other aspects: the respondents' knowledge of illegal fees at the tourist locations on Madura and the frequency at which the respondents visit a tourist location on Madura. The data from the questionnaire survey are to be compared to the data of the numbers of visits from the Culture and Tourism Services and the results of the interview with representatives of the Culture and Tourism Services of the four regencies on Madura.

The measurement of the perception on illegal fees is limited only to the illegal charging of entrance fees and parking fees at tourist locations. As mentioned in the discussion of illegal fees in the previous chapter, illegal fees in this research are restricted to illegal fees in the category of the criminal act of extortion according to Article 368 paragraph (1) of the Criminal Code and the illegal fees as part of the criminal act of corruption according to Article $12 \mathrm{e}$ of the Corruption Law.

As revealed by the questionnaire survey results, $61 \%$ of the respondents admitted to know of illegal fees imposition at tourist locations in the form of either entrance or parking fees. Three locations the respondents mentioned as having indications of illegal fees charging are 1) Jaddih Limestone Hill in Bangkalan, 2) Lombang Beach, and 3) Camplong Beach. In an interview, the representative of the Culture and Tourism Service of Bangkalan Regency stated that Jaddih Limestone Hill in Bangkalan is a tourist attraction in which there is a high indication of illegal fees imposition as it is managed by three different parties: 1) local residents in whose area some pathways run to provide an access to the tourist attraction; 2) a company managing the limestone mine; and 3) managers of the swimming pool in the Jaddih Hill tourist area.

Camplong Beach is another tourist attraction showing indications of illegal fees practice, especially on special occasions such as the Eid al-Fitr, New Year's Eve, and other holidays. According to the Culture and Tourism Service of Sampang Regency, approximately 11 entry points to Camplong Beach that are managed by local people, in addition to the official gateway, are opened over the Eid al-Fitr holiday period. Meanwhile, the illegal fees practice at Lombang Beach is not confirmed as the Culture and Tourism Service of Sumenep Regency states that of the 29 tourist destinations in Sumenep, 3 are managed directly by the service, namely 1) Slopeng Beach, 2) Lombang Beach, and 3) The Museum of the Palace of Sumenep. Instead, according to the Culture and Tourism Service of Sumenep Regency, the most advanced Tourism Awareness Groups (Pokdarwis) are found around the Lombang Beach and Slopeng Beach 
tourist areas. Since these Tourism Awareness Groups run several programs outside Lombang and Slopen tourism, and since the two tourist attractions are not directly managed by the communities, the communities open up supporting alternatives around the Lombang and Slopeng tourist areas.

From the questionnaire survey responses of the respondents and from the interviews with the representatives of the Culture and Tourism Services of the four regencies on Madura, have confirmed that illegal fees practice does exist around the tourist locations on Madura. Regarding the effect of illegal fees practice at tourist locations on the popularity of the tourist locations, the following questions are posed in this research: 1) Is the more popular a tourist location the higher the potential of illegal fees practice; and 2) Does a tourist location lose its popularity because of the practice of illegal fees there. The four tourist destinations with the highest number of visitors in each regency according to the data from the Culture and Tourism Service of each regency are not referred by the respondents as having the potential of illegal fees practice. The four tourist destinations aforementioned are 1) the Tomb of Syeichona Cholil in Bangkalan, 2) Lon Malang Beach in Sampang, 3) Jumiang Beach in Pamekasan, and 4) Asta Tinggi in Sumenep. Based on these data, the increase in popularity of a tourist attraction as marked by the number of visitors to that tourist attraction is not followed by an increase in the illegal fees practice potential at the tourist attraction.

The second question is to be answered according to the same criteria as those of the first question, that is, by using the visitor's data from the Culture and Tourism Services of the four regencies on Madura. Based on the available data from the respondents, the three locations in which illegal fees are charged — Jaddih Limestone Hill in Bangkalan, Lombang Beach in Sumenep, and Camplong Beach in Sampang - have visitation performance can be seen in Table 4.

Table 4. The Visitation Performance at the Tourist Locations Having Indications of Illegal Fees

\begin{tabular}{|c|c|c|c|c|c|}
\hline \multirow[t]{2}{*}{ No } & \multirow[t]{2}{*}{ Tourist Destination } & \multirow[t]{2}{*}{$\%$} & \multicolumn{3}{|c|}{ Visitors Data 2017-2019 } \\
\hline & & & 2017 & 2018 & 2019 \\
\hline 1 & Jaddih Limestone Hill in Bangkalan & $1 \%$ & 4,767 & 22,411 & 18,601 \\
\hline 2 & Lombang Beach in Sumenep & $5 \%$ & 60,564 & 74,236 & 45,417 \\
\hline 3 & Camplong Beach in Sampang & $11 \%$ & $29 ., 438$ & 32,383 & 79,312 \\
\hline
\end{tabular}

Data Source: Abstracted from the data on the number of visitors of the Culture and Tourism Service of each of the four regencies

Based on the Table 4, the respondents perceived as showing indications of illegal fees practice are not the favorite tourist destinations in their respective regencies. The percentage of visitors of each of the aforementioned tourist destinations did not exceed the $12 \%$ share of visitors in each regency. Jaddih Limestone Hill in Bangkalan, which is most indicated with illegal fees practice, only contributes $1 \%$ of all the visitors to Bangkalan Regency. Similarly, Lombang Beach in Sumenep and Camplong Beach in Sampang contribute only 5\% and 11\% of the whole numbers of visitors to Sumenep and Sampang Regencies, respectively.

In comparison, the data from the questionnaire survey show that $48 \%$ of the respondents said they visited the said tourist locations only once, $12.6 \%$ twice, and $39.1 \%$ more than twice. Two conclusions can be drawn from the two sets of data abovementioned. First, the tourist locations indicated with illegal fees practice are not favorites to the respondents and do not contribute a substantial number of tourists to each regency. Second, it is likely that the illegal fees practice at the tourist locations discourages tourists to return to the tourist locations as shown by the high percentage of respondents stating they only came to the tourist locations once. However, these conclusions are too shallow, and further research to a greater depth is required, given that these conclusions are not supported with data of the number of visitors. Only Camplong Beach in Sampang never experienced a decrease in the number of visitors in the three years' period prior to the pandemic, while the opposite is true for Jaddih Limestone Hill in Bangkalan and Lombang Beach in Sumenep. The decreases in the numbers of visitors to the latter two do not necessarily issue from the illegal fees practice. Other variables unexplained in this research may have their parts in these decreases.

\section{Conclussion and Suggestions}

The conclusions of this research are as follows. First, there is a low correlation between illegal fees and the undermined tourism potential on Madura. Second, there are some indications that illegal fees are charged to tourist locations that have small popularity in each regency or that, conversely, these illegal fees cause these tourist loctions to lose their visitors. This is based on the data of the share of visitors that makes up less than $12 \%$ of the total number of visitors in each regency although these data are in contrast to the popularity levels of the tourist locations indicated with illegal fees practice based on the respondents' questionnaire responses, that among the three tourist locations indicated with illegal fees practice, two are the most frequently visited by the respondents. 


\section{References}

Amaluddin, A., Payapo, R. W., Laitupa, A. A., \& Serang, M. R. (2018). A modified human development index and poverty in the villages of west seram regency, Maluku province, Indonesia. International journal of economics and financial issues, $8(2)$, 325-330.

Ekawati, R., Puspitasari, D., \& Hanifa, S. (2021). Multimodal Discourse Analysis of Religious Tourism on Madura Island, Indonesia. Journal of Business on Hospitality and Tourism, 7(1), 64-77.

Fallon, F. (2001). Conflict, power and tourism on Lombok. Current Issues in Tourism, 4(6), 481-502.

Farida, F., Zulaikha, Z., \& Hartopo, H. (2019). Use of Social Media in the Development of Halal Tourism in Madura. In 1st Annual Internatioal Conference on Social Sciences and Humanities (AICOSH 2019) (Vol. 339, pp. 12-18). Advances in Social Science, Education and Humanities Research,.

Fattah, S., \& Muji, A. (2012). Local government expenditure allocation toward human development index at jeneponto regency, South Sulawesi, Indonesia. IOSR Journal of Humanities and Social Science, 5(6), 40-50.

Funna, U. A. (2020). The Effectiveness of the Illegal Levy Eradication Task Force (Saber Pungli) In Coping with the Illegal Levy Crimes (A Study In Aceh Province). IOSR Journal Of Humanities And Social Science, 25(1), 19-24

Hamzah, M., Risqiani, R., \& Sofilda, E. (2012). Human Development Quality and Its Problems in Indonesia. OIDA International Journal of Sustainable Development, 5(7), 29-36.

Idialis, A. R. (2020). How Detect Relationship Between Tourism, Local Income, And Human Capital In Madura?. Journal Of Economics, Management, and Business Research, 1(1), 96-108.

Kusharjanto, H., \& Kim, D. (2011). Infrastructure and human development: the case of Java, Indonesia. Journal of the Asia Pacific Economy, 16(1), 111-124.

Niswaty, R., Manno, J., \& Akib, H. (2015). An analysis of the public service performance based on human development index in makassar city, Indonesia. International Journal of Applied Business and Economic Research (IJABER), 13(6), 4421-4429.

Nugraha, Y. A. (2020). The Improvement of Tourist-Village Promotion Through the Optimalization of Information and Communication Technology for Rural-Youth. International Journal of Business, Economics, and Social Development, 1(2), 90-98.

Pusra, C. M., Srinita, S., \& Seftarita, C. (2021). Effect of Selected Economic Sectors on Poverty. International Journal of Business, Economics, and Social Development, 2(1), 37-49.

Rahayuningsih, E. S. (2021). Inter-Regional Cooperation (KAD) based institution in the tourism sector in Madura. Jurnal Perspektif Pembiayaan dan Pembangunan Daerah, 9(1), 95-106.

Rahmat, A., Hardi, H., Syam, F. A., Zamzami, Z., Febriadi, B., \& Windarto, A. P. (2021, February). Utilization of the field of data mining in mapping the area of the Human Development Index (HDI) in Indonesia. In Journal of Physics: Conference Series (Vol. 1783, No. 1, p. 012035). IOP Publishing.

Sofilda, E., Hermiyanti, P., \& Hamzah, M. (2015). Determinant Variable Analysis of Human Development Index in Indonesia (Case For High And Low Index at Period 2004-2013). OIDA International Journal of Sustainable Development, 8(09), 1128.

Sudarmo, A. P. (2020). Marine Tourism Benefit from Economic Perspective (Case in Pari Island, Indonesia). International Journal of Business, Economics, and Social Development, 1(3), 105-111.

Susilowati, D., Joko, S., \& Pramuja, R. A. (2019). Quality Study of Human Development and Poverty in Madura Island. Jurnal Ekonomi Pembangunan, 17(2), 175-185.

Wantara, P., \& Irawati, S. A. (2021). Relationship and Impact of Service Quality, Destination Image, on Customer Satisfaction and Revisit Intention to Syariah Destination in Madura, Indonesia. European Journal of Business and Management Research, 6(6), 209-215.

Windari, R., \& Effendi, T. (2021). Child Rights and Human Security: Promoting Child Protection At The Tourist Attractions On Madura. International Journal of Business, Economics, and Social Development, 2(4), 162-170. 